\title{
PENGARUH PEMBERIAN DEDAK KASAR FERMENTASI PADA DOMBA EKOR TIPIS SEBAGAI BAHAN BAKU KONSENTRAT
}

\author{
Defelly Nur Tricahyani ${ }^{1}$, Suci Wulandari ${ }^{2}$, dan Suluh Nusantoro ${ }^{2}$ \\ 1 Produksi Ternak, Politeknik Negeri Jember \\ 2Jurusan Perternakan, Politeknik Negeri Jember \\ Email: defelly.tri.1985@gmail.com
}

\begin{abstract}
INTISARI
Penelitian ini bertujuan untuk mengetahui pengaruh pemberian dedak kasar fermentasi pada domba ekor tipis terhadap performa produksi domba yang meliputi konsumsi BK pakan, pertambahan berat badan (PBB), serta konversi pakan. Penelitian ini terdiri dari dua perlakuan yaitu, pakan kontrol tanpa dedak kasar fermentasi (P0) dan pemberian dedak kasar fermentasi (P1). Metode yang digunakan dalam penelitian ini adalah Uji T-test. Hasil penelitian menunjukkan bahwa pemberian dedak kasar fermentasi tidak berbeda nyata $(P>0.05)$ pada konsumsi bahan kering, pertambahan bobot badan, dan konversi pakan. Rataan PBBH tertinggi yaitu pada P1 (142,58 g/ekor/hari).
\end{abstract}

Kata kunci : Domba Ekor Tipis, Dedak Kasar Fermentasi

\section{ABSTRACT}

The aims of this study were to determine the effect of fermented rough rice bran on thin tailed sheep on sheep production performance which included feed consumption of dry ingredients feed, weight gain, and feed conversion. This study consisted of two treatments namely, (P0) rough rice brain as a control and fermented rough rice bran (P1). The method used in this research was $T$ test. The results showed that the rough bran fermentation was not significantly different $(P>0.05)$ in dry matter consumption, body weight gain, and feed conversion. The highest average gain weight was on $P 1$ (142.58 grams/head/day).

Keywors: Thin Tail Sheep, Fermented Rough Rice Bran

\section{PENDAHULUAN}

\section{Latar Belakang}

Kebutuhan protein hewani terus mengalami peningkatan dari tahun ketahun. Hal ini dikarenakan peningkatan penghasilan dan pengetahuan masyarakat akan pentingnya mengkonsumsi protein hewani. Kondisi di lapangan menunjukkan bahwa komoditas ternak domba berperan sebagai pemasok kebutuhan daging nasional sekitar 84.550 ton daging domba per tahun setara dengan sekitar 2,8 juta domba dengan bobot 30 kg per ekor (Statistik pertanian 2004 dalam Kushartono 2005).

Domba merupakan ternak ruminansia kecil yang sudah lama dikenal masyarakat. Domba cukup potensial untuk dikembangkan karena domba mudah beradaptasi dan perkembangbiakannya cepat karena seekor domba dapat beranak 3 kali dalam 2 tahun dan sekali kelahiran dapat menghasilkan 2 sampai 3 ekor anak (Purbowati 2009). 
Pada saat ini penggemukan domba cukup diminati oleh masyarakat, faktor yang menentukan penggemukan domba terletak pada kualitas dan kuantitas pakan. Pakan adalah salah satu kebutuhan pokok domba yang harus terpenuhi agar domba dapat tumbuh dan bertahan hidup. Pakan utama domba adalah hijauan, tetapi akhir-akhir ini ketersediaan hijauan mulai terbatas. Keterbatasan hijauan disebabkan karena keterbatasan lahan penggembalaan dan penyediaan hijauan pakan ternak yang mulai beralih fungsi dari lahan produktif menjadi lahan pemukiman dan kawasan industri. Oleh karena itu, perlu pakan alternatif sebagai pengganti hijauan yaitu dengan memanfaatkan sumberdaya lokal yang berupa limbah pertanian.

Potensi penggunaan dedak sebagai bahan baku di Indonesia amat besar, karena Indonesia merupakan negara agraris. Produksi padi Tahun 2015 adalah 75.397.841 ton, dimana 8 sampai 10 persen berupa dedak padi yaitu sekitar 6.031.827 sampai 7.539.784 ton. Sekam yang dihasilkan 18 sampai 20 persen, yaitu sebesar 13.571.611 sampai 15.079.568 ton (BPS, 2015). Dedak memiliki fungsi dalam pakan yaitu sebagai sumber karbohidrat dan protein, namun dedak kasar kandungan seratnya cukup tinggi, karena merupakan campuran antara dedak dan sekam. Kandungan nutrisi dedak kasar adalah: 90,68\% (bahan kering/ BK), 5,95\% (protein kasar/PK), 32,45\% (serat kasar/SK), dan 44,1\% (TDN) (Laboratorium Teknologi Pakan, Politeknik Negeri Jember, 2016). Oleh karena itu dibutuhkan usaha untuk meningkatkan nutrisi dedak tersebut. Salah satu solusinya adalah dengan fermentasi.

Fermentasi adalah bioteknologi yang dapat diterapkan untuk mengolah dedak kasar menjadi pakan yang disenangi oleh ternak, karena pada saat proses fermentasi terdapat perombakan struktur yang komplek menjadi sederhana sehingga daya cerna lebih efisien, karena dengan fermentasi serat kasar yang tinggi dapat didegredasi menggunakan mikroorganisme. Proses fermentasi dilakukan untuk meningkatkan nilai gizi bahan kualitas rendah, pengawetan bahan pakan, dan merupakan suatu cara untuk menghilangkan zat anti nutrisi atau racun yang terkandung dalam suatu bahan pakan. Selain itu, proses fermentasi dapat memperpanjang masa penyimpanan, mengendalikan pertumbuhan mikrobia, mempertahankan gizi yang dikehendaki, dan menciptakan kondisi yang kurang memadai untuk mikrobia kontaminan. Fermentasi bahan pakan dapat menggunakan bakteri atau jamur seperti: bakteri asam laktat, bakteri selulotik dan jamur Trichoderma viridae. Proses fermentasi bahan pakan dalam penelitian ini menggunakan EM4 (Effective microorganisme). Larutan EM-4 merupakan suatu kultur campuran berbagai mikroorganisme yang bermanfaat terutama Lactobacillus, bakteri fotosintetik, actynomycetes, ragi, dan jamur fermentasi.

Berdasarkan uraian latar belakang di atas, peneliti ingin mengetahui manfaat dedak kasar fermentasi pada penggemukan domba jantan lokal. 


\section{Tujuan Penelitian}

1. Untuk meningkatkan nilai nutrisi dedak kasar.

2. Untuk meningkatkan performa domba dengan penggunaan dedak kasar fermentasi.

3. Memanfaatkan limbah pertanian berupa dedak kasar dengan di fermentasi sebagai pengganti hijauan.

\section{Manfaat}

Hasil penelitian ini diharapkan mampu memberikan informasi kepada masyarakat atau peternak tentang seberapa jauh penggunaan dedak kasar fermentasi sebagai bahan pakan ternak yang dapat meningkatkan pertumbuhan bobot badan, konsumsi pakan, dan konversi pakan domba jantan lokal.

\section{MATERI DAN METODE}

Kegiatan penelitian ini telah dilaksanakan pada tanggal 20 Juni 2016 sampai dengan 17 September 2016 di kandang milik Bapak Galih Yandika di Jalan Darmawangsa VI/19 Desa
Kaliwining, Kecamatan Rambipuji, Kabupaten Jember.

Peralatan yang digunakan dalam penelitian ini adalah kandang, lampu, sekop, sapu lidi, timbangan, kapur, tempat pakan, tempat minum, timba, alat tulis, kalkulator dan recording. Bahan yang digunakan adalah domba jantan lokal yang baru tumbuh (sekitar 8 bulan sampai 1 tahun dengan kisaran berat badan 18 sampai $23 \mathrm{~kg}$ ), rumput lapang, dedak kasar fermentasi, EM-4, tetes, desinfektan, vitamin B komplek dan obat cacing. Berikut kandungan bahan pakan dan formulasinya. Analisis data menggunakan Uji $\mathrm{T}$ untuk membedakan pengaruh dari perlakuan pemberian dedak kasar fermentasi pada performa domba, dengan menggunakan Statistical Product and Service Solutions 16 (SPSS 16).

\section{Parameter yang Diamati}

Parameter pengamatan dalam penelitian ini adalah pertambahan bobot badan perminggu, pertambahan bobot akhir, konsumsi pakan, dan konversi pakan ternak domba jantan lokal.

Tabel 1. Bahan dan komposisi pakan yang digunakan dalam penelitian (\%)

\begin{tabular}{clrrrr}
\hline No. & \multicolumn{1}{c}{ Bahan Pakan } & BK & PK & SK & TDN \\
\hline 1 & Rumput lapang & 22,93 & 8,59 & 36,38 & 57,31 \\
2 & Dedak kasar & 90,68 & 5,95 & 32,45 & 44,11 \\
3 & Dedak kasar fermentasi & $94,79^{*}$ & $2,175^{* *}$ & $32,45^{*}$ & $36,99^{*}$ \\
4 & Bekatul & 90,91 & 12,75 & 14,12 & 68,14 \\
5 & Bungkil kedelai & 86 & 48 & 6,2 & 81 \\
6 & Biji gandum & 86 & 13,6 & 3,5 & 85 \\
\hline
\end{tabular}

Sumber: ${ }^{*}$ Laboratorium Teknologi Pakan Ternak POLIJE (2016)

${ }^{* *}$ Laboratorium Biosain POLIJE (2016) 


\section{Konsumsi Pakan}

Pengambilan data konsumsi pakan diambil setiap hari selama pemeliharaan berlangsung yaitu dengan cara menghitung selisih antara jumlah pakan yang diberikan dengan jumlah pakan yang tersisa yang dinyatakan dalam gram per ekor/hari.

\section{Pertambahan Bobot Badan}

Data pertambahan bobot badan diperoleh dari hasil penimbangan domba pada akhir minggu dengan hasil penimbangan pada awal minggu yang dilakukan seminggu sekali.

$$
\text { PBBH }=\frac{\text { Bobot Akhir }- \text { Bobot Awal }}{\text { Lama Hari Penimbangan }}
$$

Keterangan: lama hari penimbangan dinyatakan dalam gram per ekor/hari.

\section{Konversi Pakan}

Perhitungan konversi pakan atau FCR (Feed Convertion Ratio) dilakukan tiap minggu. Konversi pakan diperoleh dengan cara membandingkan konsumsi pakan dengan pertambahan bobot badan.

$$
F C R=\frac{\text { Konsumsi Pakan }}{\text { Pertambahan Bobot Badan }}
$$

\section{Pembuatan Dedak Kasar Fermentasi}

Pembuatan dedak kasar fermentasi menggunakan dedak kasar dan tetes sebagai bahan utama dan EM-4 sebagai fermentornya. Prosedur pembuatan dedak kasar fermentasi adalah sebagai berikut:

a. Mengaktifkan EM-4 dengan cara melarutkan 4 cc EM-4 dalam 1 liter larutan tetes lalu didiamkan selama 1 jam.

b. Tetes disiapkan sebanyak $5 \%$ dari berat pakan yang akan di fermentasi.

c. EM-4 yang telah aktif dicampur dengan dedak kasar dan sisa tetes sampai homogen (kandungan kadar air 53\% atau sampai kondisi menggumpal jika dikepal (memal)).

d. Dedak kasar di masukkan ke silo, dipadatkan sedikit demi sedikit sambil ditekan dan tutup rapat (an-aerob), kemudian diperam selama 7 hari hingga terbentuklah dedak kasar fermentasi.

Tabel 2. Formulasi Pakan Dedak Kasar Fermentasi Dan Non Fermentasi (\%).

\begin{tabular}{cccc}
\hline \multirow{2}{*}{ No } & \multirow{2}{*}{ Bahan Pakan } & \multicolumn{2}{c}{ Proporsi } \\
\cline { 3 - 4 } & & Dedak Kasar Fermentasi ${ }^{\mathrm{A} 1}$ & ${\text { Dedak Kasar Non Fermentasi }{ }^{\mathrm{A} 2}}$ \\
\hline 1 & Rumput lapang & 27 & 30 \\
2 & Dedak kasar & 30 & 35 \\
3 & Bekatul & 16 & 15 \\
4 & Bungkil kedelai & 10 & 7 \\
5 & Biji gandum & 17 & 13 \\
\hline \multicolumn{2}{c}{ TOTAL } & 100 & 100 \\
\hline
\end{tabular}

${ }^{\mathrm{A} 1} \mathrm{BK}(\mathrm{kg})=0,72 ; \mathrm{PK}(\%)=12,12 ; \mathrm{SK}(\%)=23,03 ; \operatorname{TDN}(\%)=60,02$

${ }^{\mathrm{A} 2} \mathrm{BK}(\mathrm{kg})=0,69 ; \mathrm{PK}(\%)=12,19 ; \mathrm{SK}(\%)=23,65 ; \operatorname{TDN}(\%)=61,91$ 


\section{Pemberian Pakan dan Minum}

Pemberian pakan diberikan

berdasarkan BK. Air minum diberikan secara adlibitum. Pakan diberikan 2 kali sehari, yaitu pada pukul 08.00 dan pada pukul 16.00 WIB. Cara pemberian pakan dedak kasar fermentasi yaitu setelah dedak kasar fermentasi di panen, diangin-anginkan, lalu dicampurkan dengan bahan-bahan lainnya seperti: bekatul, bungkil kedelai, dan biji gandum.

\section{Adaptasi Pakan}

Adaptasi pakan dilakukan saat awal pemeliharaan. Ternak diberi waktu adaptasi selama 3 minggu, dilanjutkan pengumpulan data performa produksi dilaksanakan selama 90 hari.

\section{Pengambilan Data}

Data yang diambil bobot badan domba diawal pemeliharaan dan diakhir saat akan panen.

\section{HASIL DAN PEMBAHASAN}

Fermentasi dapat meningkatkan nilai nutrisi, tetapi pada penelitian ini fermentasi tidak meningkatkan nilai nutrisi pada dedak kasar, dapat dilihat pada Tabel 1 PK dan TDN mengalami penurunan. Hal ini diduga mikrobia pendegradasi serat yang berkembang selama fermentasi memanfaatkan nutrien terlarut untuk pertumbuhan awalnya. Hal ini sesuai dengan penelitian Wulandari (2003) bahwa penambahan inokulan pendegradasi serat berupa kapang $P$. Crysosporium akan memanfaatkan zat-zat yang ada dalam isi sel bahan pakan dan hemiselulosa untuk pertumbuhan dirinya maupun untuk memproduksi enzim.

\section{Konsumsi Pakan}

Konsumsi pakan adalah selisih antara pakan yang diberikan dengan sisa pakan. Rataan konsumsi pakan pada domba jantan ekor tipis yang diberi dedak kasar fermentasi dan dedak kasar non fermentasi dapat dilihat pada Tabel 3.

Hasil analisis statistik menunjukkan perbedaan tidak nyata $(\mathrm{P}>0,05)$ diantara kedua perlakuan. Hal ini menunjukkan bahwa pemberian dedak fermentasi tidak mempengaruhi nilai konsumsi pada domba jika dibandingkan dengan dedak tanpa fermentasi, namun berdasarkan data bahan kering konsumsi pakan (Tabel 3) di atas menunjukkan ada kecenderungan peningkatan konsumsi bahan kering selama penelitian. Domba jantan ekor tipis dengan pemberian dedak kasar fermentasi diperoleh rataan sebesar 1.714,34 gram/ekor atau 6,3\% dari bobot badan, sedangkan domba jantan ekor tipis dengan pemberian dedak kasar non fermentasi diperoleh rataan sebesar 1.225,31 gram/ekor atau 5\% dari bobot badan. Ranjhan (1981) menyatakan bahwa konsumsi BK sekitar 3-5\% dari bobot hidup, pada penelitian ini konsumsi BK melebihi dari angka BK maksimal. Hal ini dikarenakan pemberian pakan diberikan secara adlibitum 
dan fermentasi dedak tidak mempengaruhi konsumsi (palatabilitas). Hal ini nampak pada hasil statistik yang menunjukkan peningkatan konsumsi dedak fermentasi yang tidak berbeda nyata $(\mathrm{P}>0,05)$. Menurut Wulandari (2014), bahwa faktor yang mempengaruhi konsumsi pakan yaitu meliputi ternak yang bersangkutan, pakan yang diberikan, dan kondisi lingkungan tempat ternak tersebut dipelihara.

\section{Pertambahan Bobot Badan}

Pertambahan bobot badan (PBB) merupakan salah satu ciri dari adanya pertumbuhan seekor ternak. Kecepatan pertumbuhan selalu berbeda-beda. Perbedaan tersebut dipengaruhi oleh bangsa domba, umur, jenis kelamin, genetik, dan lingkungan. Tinggi rendahnya pertambahan bobot badan bulanan sangat dipengaruhi oleh kualitas pakan. PBB domba dapat dilihat pada Tabel 4.

Penelitian dengan pemberian dedak kasar fermentasi menunjukkan PBB mengalami peningkatan sebesar $14,9 \%$. PBB merupakan cermin kualitas pakan yang diberikan. Dedak kasar fermentasi cenderung meningkatkan PBB yang tertinggi (Tabel 4). Meskipun pada hasil perhitungan menunjukkan berbeda tidak nyata $(\mathrm{P}>0,05)$. Hal ini karena konsumsi pakan yang tidak berbeda, sehingga menghasilkan PBB yang tidak berbeda pula, meskipun ada kecenderungan peningkatan PBB untuk domba yang diberi pakan dedak fermentasi. Kondisi ini sesuai dengan pendapat Kartadisastra (1997) bahwa berat badan ternak senantiasa berbanding lurus dengan tingkat konsumsi pakannya. Tidak berpengaruh secara nyata terhadap PBB domba yang diberi pakan dedak kasar fermentasi terhadap PBB domba yang diberi pakan dedak kasar tanpa fermentasi ini disebabkan pula oleh kandungan nutrien pakan kedua perlakuan tersebut dapat mencukupi kebutuhan nutrisi ternak domba, yaitu PK sekitar 12\% dan TDN sebesar 60 sampai 61\% (Tabel 2). Menurut Parakkasi (1987) bahwa pertambahan berat badan dipengaruhi oleh konsumsi nutrien pakan, dan dinyatakan pula oleh Handayanta (2004) bahwa konsumsi protein dan energi merupakan faktor yang menentukan pertambahan berat badan.

Tabel 3. Rataan Konsumsi Pakan Berdasar BK dan Segar (g/ekor/hari).

\begin{tabular}{ccccc}
\hline \multirow{2}{*}{ Domba } & \multicolumn{4}{c}{ Perlakuan } \\
\cline { 2 - 5 } & Non Fermentasi $^{1}$ & Fermentasi $^{1}$ & Non Fermentasi $^{2}$ & Fermentasi $^{2}$ \\
\hline 1 & $1.012,18$ & $1.829,34$ & $1.458,15$ & $2.526,93$ \\
2 & $1.611,6$ & $1.681,26$ & $2.321,74$ & $2.322,39$ \\
3 & $1.052,17$ & $1.632,43$ & $1.515,77$ & $2.068,82$ \\
Total & $3.675,95$ & $5.143,03$ & $5.295,66$ & $6.918,14$ \\
\hline Rataan & $1.225,31$ & $1.714,34$ & $1.765,22$ & $2.306,04$ \\
\hline Signifikansi & 0,07 ns & & & \\
\hline ns Tidak berbeda nyata (non significant) pada BK & & \\
${ }^{1}$ Konsumsi pakan berdasar BK ${ }^{2}$ Konsumsi pakan berdasar segar &
\end{tabular}




\section{Konversi Pakan}

Nilai konversi merupakan gambaran dari efisiensi penggunaan oleh ternak. Efisiensi penggunaan pakan dapat dilihat dari besar kecilnya nilai konversi. Semakin kecil nilai konversi, maka semakin efisien ternak dalam menggunakan pakan untuk produksi daging. Sebaliknya, jika nilai konversi semakin besar, maka ransum tersebut tidak efisien digunakan oleh ternak. Pemberian pakan yang banyak tidak memberikan kontribusi yang lebih terhadap produksi daging dibandingkan dengan pemberian pakan yang jumlahnya sedikit. Nilai konversi masing-masing perlakuan ditunjukkan pada Tabel 5.

Data konversi pakan pada (Tabel pemberian dedak kasar fermentasi diperoleh rataan 12,14 dan pemberian dedak kasar non fermentasi diperoleh rataan sebesar 10,26. Hasil analisis statistik menunjukkan perbedaan tidak nyata $(\mathrm{P}>0,05)$ diantara kedua perlakuan. Menurut Purbowati et al. (2009) bahwa konversi pakan domba di daerah tropis berkisar antara 7 sampai 15, artinya untuk menghasilkan $1 \quad \mathrm{~kg}$ PBB dibutuhkan BK pakan sebanyak 7 sampai 15 kg. Data tersebut menunjukkan bahwa domba ekor tipis dapat memanfaatkan dedak kasar baik tanpa fermentasi maupun dengan fermentasi sabagai bahan pakan dalam ransumnya, dengan tetap memperhitungkan kandungan nutrisi ransum sesuai kebutuhannya.

Tabel 4. Rataan Pertambahan Bobot Badan (g/ekor/hari)

\begin{tabular}{cccc}
\hline \multirow{2}{*}{ Domba } & \multicolumn{2}{c}{ Perlakuan } & \multirow{2}{*}{ Signifikansi } \\
\cline { 2 - 3 } & Non Fermentasi & Fermentasi & \\
2 & 144,40 & 166,66 & \\
3 & 144,40 & 138,88 & \\
Total & 83,33 & 122,22 & \\
\hline Rataan & 372,10 & 427,76 & $0,48^{\text {ns }}$ \\
\hline
\end{tabular}

ns tidak berbeda nyata (non significant).

Tabel 5. Rataan Konversi Pakan.

\begin{tabular}{cccc}
\hline \multirow{2}{*}{ Domba } & \multicolumn{2}{c}{ Perlakuan } & \multirow{2}{*}{ Signifikansi } \\
\cline { 2 - 4 } & Non Fermentasi & Fermentasi & \\
\hline 1 & 7,00 & 10,97 & \\
3 & 11,16 & 12,10 & \\
Total & 12,63 & 13,35 & $0,36^{\text {ns }}$ \\
\hline Rataan & 30,79 & 36,42 & 12,14 \\
\hline
\end{tabular}

ns Tidak berbeda nyata (non significant) 


\section{PENUTUP}

\section{Kesimpulan}

Penelitian ini dapat disimpulkan bahwa dedak kasar fermentasi tidak meningkatkan nilai nutrisi pada dedak kasar. Pemberian dedak kasar fermentasi pada domba ekor tipis tidak mempengaruhi konsumsi pakan, pertambahan bobot badan, dan konversi pakan. Terjadi peningkatan petambahan bobot badan pada domba ekor tipis yang dipelihara selama dua bulan dengan rata-rata sebesar 124,03 gram/ekor/hari (pemberian dedak non fermentasi) dan 142,58 gram/ekor/hari (pemberian dedak fermentasi).

\section{Saran}

Perlu dikaji ulang lebih lanjut dengan memakai bahan fermentor lain selain EM-4 dan perlu dilakukan uji kecernaan pakan hasil fermentasi.

\section{DAFTAR PUSTAKA}

Badan Pusat Statistik. 2015. Produksi Padi Menurut Provinsi 2015. http://www.bps.go.id/linkTableDinami s/view/id/865. Diakses tanggal 15 September 2017.

Handayanta, E. 2004. Pengaruh substitusi rumput raja dengan pucuk tebu dalam ransum terhadap performa sapi jantan Friesian Holstein. Sains Peternakan Jurnal Penelitian Ilmu Peternakan. Jurusan Produksi Ternak Fakultas Pertanian Universitas Sebelas Maret. Surakarta. 1(2):49-56.

Kartadisastra, H. R. 1997. Penyediaan dan Pengolahan Pakan Ternak Ruminansia. Kanisius. Yogyakarta.

Kushartono, B., dan N. Iriani. 2005. Silase tanaman jagung sebagai pengembangan sumber pakan ternak. Prosiding temu teknis nasional tenaga fungsional pertanian. Balai Penelitian Ternak. Bogor.

Parakkasi, A. 1987. Ilmu Gizi Makanan Ternak Monogastrik. Angkasa. Bandung.

Purbowati, E. 2009. Karakteristik fisik otot longissimus dorsi dan biceps femoris domba lokal jantan yang dipelihara di pedesaan pada bobot potong yang berbeda. Jurnal Protein (13)2:147-153.

Purbowati, E., C. I. Sutrisno, E. Baliarti, S. P. S. Budhi, W. Lestariana, E. Rianto, dan Kholidin. 2009. Penampilan produksi domba lokal jantan dengan pakan komplit dari berbagai limbah pertanian dan agroindustri. Prosiding Seminar Nasional Kebangkitan Peternakan. Semarang. (1):130-138.

Ranjhan, S. K. 1981. Animal Nutrition in The Tropics. Vicas Publishing House PVT Ltd. New Delhi.

Wulandari, S., 2003. Pengaruh prehidrolisis enzimatis dari Phanerochaete crysosporium dan pemberian inokulan Lactobacillus plantarum terhadap nilai nutrisi silase rumput gajah. Jurnal Pengembangan Peternakan Tropis. Special Edition. Oktober 2003.

Wulandari, S. 2014. Performa produksi domba yang diberi complete feed fermentasi berbasis pod kakao serta nilai nutrien tercerna secara in vivo. Buletin Peternakan. 38(1):42-50. 